\title{
PEMBARUAN PENDIDIKAN ISLAM DALAM KONTEKS PENDIDIKAN NASIONAL
}

\author{
Oleh: Muh. Idris*
}

\begin{abstract}
The transformation of education needs a new way of thinking and practice by complete paradigm shift. It needs a systemic paradigm and emphasizes a basic change in other aspect. Vision in Islamic education development refers to educational reformation and modernization. This point of view is based on monotheism concept combining science and technology. The implications of this vision can be described as follows: developing the branch faculty of IAIN in to independent STAIN, opening wider mandate by developing study programs and converting STAIN and IAIN to be UIN. This is a conversion which may lead Islamic education institutions to play important role in developing science and technology, and to be more competitive in the global era. Hence, Islamic institutions will be the center of excellence in education and culture to develop human civilization, and be the centre of relevant workforce provision.
\end{abstract}

KEYWORDS: Pembaruan, pendidikan Islam, pendidikan nasional

DUNIA Pendidikan ${ }^{1}$ sudah menjadi sumber pembaruan dalam merespons tantangan dan dinamika dalam era globalisasi dan modernisasi. STAIN dan IAIN tidak memadai lagi pencernaannya dalam menghadapi globalisasi saat ini. Islam berbicara puasa, zakat bahkan peristiwa isra-mikraj dan lain sebagainya. Hal itu dapat dipahami, misalnya, puasa bermakna kesehatan, maka lembaga pendidikan Islam dianjurkan mengembangkan ilmu-ilmu kesehatan. Zakat dapat dimaknai ekonomi, isra-mikraj dapat dipahami sains dan teknologi. Ilmu-ilmu tersebut diupayakan dibangun dan dikembangkan sebagai respons positif dan konstruktif agar pendidikan Islam lebih kompatibel dan marketabel dalam merespons tantangan itu.

Mastuhu mengakui, sebagaimana dikutip Suwito, bahwa tantangan dunia akademik penuh dengan kritik dan perdebatan mengenai masalahmasalah pendidikan. Hal tersebut tidak pernah selesai dan tidak terelakkan. Hal ini disebabkan karena salah satu keunikan dalam kehidupan

*Doktor dalam bidang pendidikan Islam pada Sekolah Pascasarjana Universitas Islam Negeri Syarif Hidayatullah Jakarta ini adalah dosen tetap pada Sekolah Tinggi Agama Islam Negeri Manado. 
manusia tidak pernah sepi dari nilai-nilai luhur yang dicita-citakan. Sementara itu, manusia memang mampu membuat berbagai pertanyaan dan menciptakan berbagai jalan yang semakin lama semakin maju dan canggih. Akan tetapi, Mastuhu juga mengakui bahwa manusia belum pernah memperoleh jawaban final yang memuaskan hidupnya. Manusia selalu berada dalam proses terus-menerus mencari jawaban. ${ }^{2}$

Sistem pendidikan nasional yang telah dibangun selama tiga dasawarsa terakhir ini ternyata belum mampu sepenuhnya menjawab kebutuhan dan tantangan nasional dan global dewasa ini. Program pemerataan dan peningkatan kualitas pendidikan yang selama ini merupakan fokus pembinaan masih menjadi masalah yang paling menonjol dalam dunia pendidikan.

Diakui Azyumardi Azra bahwa hampir seluruh negara muslim tidak mempunyai kebijakan (policy) dan perencanaan nasional yang jelas, menyeluruh, terpadu, dan terarah untuk pengembangan sains. Bahkan, dalam banyak kasus merupakan bidang yang paling terlantar dari kebijaksanaan nasional yang terlalu bertitik tekan pada pertumbuhan ekonomi. ${ }^{3} \mathrm{Hal}$ ini kontras dengan negara-negara maju yang memberikan perhatian khusus pada kebijaksanaan pendidikan dalam arti luas, bahkan melebihi kebijaksanaan luar negeri atau militer. Sebab, kegagalan pada pengembangan pendidikan nasional secara luas dapat menghambat perkembangan secara menyeluruh di masa depan. ${ }^{4}$

Tantangan dan perkembangan lingkungan strategis, baik nasional maupun internasional, dalam berbagai bidang kehidupan semakin berat. Perkembangan ilmu pengetahuan dan teknologi, khususnya di bidang informasi, komunikasi dan transportasi yang amat cepat, eskalasi pasar bebas antarnegara dan bangsa yang semakin meningkat, iklim kompetisi dalam berbagai bidang kehidupan yang semakin ketat, dan tuntutan demokratisasi serta masalah hak azasi manusia merupakan tantangan yang harus dijawab oleh bangsa Indonesia agar bisa hidup terus dan bertahan dalam percaturan kehidupan antarbangsa di dunia. ${ }^{5}$

Bangunan pendidikan selama ini berpedoman pada konsep inputoutput analysis. ${ }^{6}$ Paradigma yang mempunyai akar teori pada bidang ekonomi produksi ini berkeyakinan bahwa apabila input diperbaiki, maka secara otomatis output akan menjadi baik pula. Ini dikarenakan lembaga pendidikan tidak bisa disamakan dengan pabrik dalam dunia industri, sebab input pendidikan bukan input yang statis melainkan input dinamis yang banyak dipengaruhi oleh berbagai faktor, khususnya faktor proses dan konteks pendidikan dewasa ini. 


\section{PENDIDIKAN ISLAM}

Dalam sejarah pendidikan Indonesia maupun dalam studi kependidikan, sebutan pendidikan Islam umumnya dipahami sebatas sebagai "ciri khas" jenis pendidikan yang berlatar belakang keagamaan. Demikian pula batasan yang ditetapkan dalam Undang-undang Nomor 2 Tahun 1989 tentang Sistem Pendidikan Nasional. ${ }^{7}$ Batasan yang sama juga terdapat dalam Undang-undang Nomor 20 Tahun 2003 tentang Sistem pendidikan Nasional. ${ }^{8}$

A. Malik Fadjar (selanjutnya disebut Malik Fadjar) ketika mengutip pendapat Zarkowi Soejoeti mengemukakan bahwa Pendidikan Islam paling tidak mempunyai tiga pengertian. Pertama, lembaga pendidikan Islam itu pendirian dan penyelenggaraannya didorong oleh hasrat mengejawantahkan nilai-nilai Islam yang tercermin dalam nama lembaga pendidikan itu dan kegiatan-kegiatan yang diselenggarakan. Dalam pengertian ini, Islam dilihat sebagai sumber nilai yang harus diwujudkan dalam kehidupan lembaga pendidikan yang bersangkutan. Kedua, lembaga pendidikan yang memberikan perhatian dan yang menyelenggarakan kajian tentang Islam yang tercermin dalam program kajian sebagai ilmu dan diperlakukan sebagai ilmu-ilmu lain yang menjadi program kajian lembaga pendidikan Islam yang bersangkutan. Ketiga, mengandung dua pengertian di atas dalam arti lembaga tersebut memperlakukan Islam sebagai sumber nilai bagi sikap dan tingkah laku yang harus tercermin dalam penyelenggaraannya maupun sebagai bidang kajian yang tercermin dalam program kajiannya. ${ }^{9}$

Konsep pendidikan Islam sebagaimana yang dikemukakan oleh Zarkowi Soejoeti tersebut walaupun belum memadai secara falsafi untuk disebut sebagai pendidikan Islam, tetapi dapat dijadikan sebagai pengantar dalam memahami pendidikan Islam secara lebih mendasar. ${ }^{10}$

Berdasarkan pengertian ini, Malik Fadjar berpendapat bahwa keberadaan pendidikan Islam tidak sekedar menyangkut persoalan ciri khas, melainkan lebih mendasar lagi yaitu tujuan yang diidamkan dan diyakini sebagai yang paling ideal yaitu insān kāmil atau muslim paripurna. ${ }^{11}$

Tujuan ini sekaligus mempertegas bahwa misi dan tanggung jawab yang diemban pendidikan Islam lebih berat lagi. Dalam pembicaraan ini jenis dan pengertian pendidikan Islam mencakup ketiga-tiganya, karena memang ketiga-tiganya itu yang selama ini tumbuh serta berkembang di Indonesia dan sudah menjadi bagian yang tidak terpisahkan dari sejarah maupun kebijakan pendidikan secara nasional. Bahkan, tidak berlebihan kalau secara politis dikatakan bahwa kehadiran dan keberadaannya meru- 
pakan bagian dari andil umat Islam dalam perjuangan maupun dalam mengisi kemerdekaan. ${ }^{12}$

Azyumardi Azra berpendapat bahwa banyak yang bisa dijual dari Islam, ${ }^{13}$ termasuk aspek disiplin, kerja keras, keadilan, demokrasi, musyawarah, HAM, perdamaian dan semacamnya. Orang Islam percaya bahwa Islam adalah rahmatan li al-älamin. Oleh karena itu, pendidikan Islam bertujuan menciptakan insān kāmil. Terbinanya kepribadian muslim atau insān kāmil yang merupakan ketetapan tujuan pendidikan Islam masih merupakan idea statis, tetapi kualitasnya dinamis dan berkembang nilainilainya. Tujuan pendidikan Islam itu sarat dengan nilai-nilai fundamental yang memungkinkan terwujudnya kepribadian muslim atau insān kāmil yaitu yang kondisi fisik dan mentalnya merupakan satu kesatuan secara terpadu. Sehingga dalam penampilan dan kegiatannya tidak terjadi dikotomi antara jasmani dan rohani, duniawi dan ukhrawi. ${ }^{14}$ Konsep integralitas keilmuan bertujuan menjadi cerminan insan yang paripurna.

Sedangkan menurut Hamka, untuk membentuk peserta didik yang memiliki kepribadian paripurna, maka eksistensi pendidikan agama merupakan sebuah kemestian yang harus diajarkan, meskipun pada sekolahsekolah umum. Namun, dalam tataran operasional prosesnya tidak hanya dilakukan sebatas mentransfer ilmu pengetahuan, tetapi jauh lebih penting adalah bagaimana ilmu yang mereka peroleh mampu membuahkan suatu sikap yang baik sesuai dengan pesan nilai ilmu yang dimilikinya. ${ }^{15}$

Hal ini sejalan dengan apa yang dikemukakan oleh Muhammad Abduh (1848-1905) yang menyatakan bahwa pendidikan yang baik adalah pendidikan yang dalam prosesnya mampu mengembangkan seluruh fitrah peserta didik terutama fitrah akal dan agamanya. Dengan fitrah ini peserta didik akan dapat mengembangkan daya berpikir secara rasional. Sementara melalui fitrah agama akan tertanam pilar-pilar kebaikan pada diri peserta didik yang selanjutnya terimplikasi dalam seluruh aktivitas hidupnya. ${ }^{16}$

Dalam konteks ini sejalan dengan pandangan Malik Fadjar bahwa agama adalah sains dan akal adalah teknologi. Untuk itu, tugas utama pendidikan adalah menciptakan sosok peserta didik berkepribadian yang paripurna.

Sedangkan berkaitan dengan tujuan pendidikan Islam, Athiyah alAbrasyi dalam kajiannya tentang pendidikan Islam menyimpulkan lima tujuan yang asasi dalam pendidikan Islam, yaitu: untuk membantu pembentukan akhlak yang mulia, mempersiapkan kehidupan dunia dan akhirat, mempersiapan untuk mencari rezeki dan menjaga kemaslahatan, menumbuhkan roh ilmiah pada anak didik dan memenuhi rasa keingin- 
tahuannya serta memungkinkan untuk mengkaji berbagai ilmu, menyiapkan anak didik untuk menguasai profesi tertentu. ${ }^{17}$ Di samping itu dengan pendidikan, seseorang dimungkinkan mengenal diri dan alam sekitarnya. ${ }^{18}$

Ahmad Tafsir menyatakan bahwa tujuan pendidikan terkait dengan pandangan hidup. Jika pandangan hidupnya adalah Islam, maka tujuan pendidikan harus dari ajaran Islam. ${ }^{19}$ Pendidikan akan mewujudkan keseimbangan diri seseorang dalam bentuk pemenuhan kebutuhan badan, jiwa, pikiran, dan perbuatan yang akan melahirkan akhlak yang mulia, kasih sayang, dan tolong menolong. ${ }^{20}$

Al-Kailani menyatakan bahwa pendidikan Islam berorientasi pada kelangsungan eksistensi manusia dan juga peningkatan harkat kemanusiaannya. ${ }^{21}$ Sedangkan menurut al-Nahlawi, tujuan pendidikan Islam adalah pembebasan dan penyelamatan anak didik. ${ }^{22}$ Sehingga ia dapat mengenal agama, baik secara teori maupun prakteknya. ${ }^{23}$ Sementara itu Muhammad Abduh menjelaskan bahwa tujuan pendidikan adalah mendidik akal dan jiwa dan menyampaikannya kepada batas-batas kemungkinan seseorang mencapai kebahagiaan hidup di dunia dan akhirat. ${ }^{24}$ Dari rumusan ini dapat diketahui bahwa tujuan pendidikan yang ingin dicapai oleh Muhammad Abduh adalah tujuan yang luas, mencakup aspek akal dan aspek spiritual. Tujuan pendidikan tersebut diprediksi dalam rangka pencapaian hasil. 25

Pendidikan perlu menjadi bekal demi kesiapan manusia untuk memahami keberagaman manifestasi nilai-nilai dalam peri kehidupannya sebagai anggota masyarakat. ${ }^{26}$ Peserta didik harus diperkenalkan pada berbagai bidang. Perkenalan itu akhirnya membuka perspektif bagi seseorang untuk membuat pilihan, apakah ia ingin menjadi homo religiosus, homo aestheticus, homo politicus, homo economicus, homo academicus, dan sebagainya. ${ }^{27}$

Azyumardi Azra menjelaskan bahwa pendidikan Islam mempunyai beberapa karakteristik, yaitu: Pertama, penekanan pada pencarian ilmu pengetahuan, penguasaan dan pengembangan atas dasar ibadah kepada Allah. Kedua, pengakuan akan potensi dan kemampuan seseorang untuk berkembang dalam suatu kepribadian, setiap pencari ilmu dipandang sebagai makhluk Tuhan yang perlu dihormati dan disantuni, agar potensipotensi yang dimilikinya dapat teraktualisasi dengan sebaik-baiknya. Ketiga, pengamalan ilmu pengetahuan atas dasar tanggung jawab kepada Tuhan dan masyarakat manusia. Di sini pengetahuan bukan hanya untuk diketahui dan dikembangkan, melainkan sekaligus dipraktekkan dalam kehidupan nyata. Dengan demikian terdapat konsistensi antara apa-apa yang diketahui dengan pengamalannya dalam kehidupan sehari-hari. ${ }^{28}$ 
Pendidikan memang bukan sekadar transfer pengetahuan, pembinaan mental jasmani dan intelek semata, tetapi bagaimana pengetahuan dan pengalaman yang telah didapatkan dipraktekkan dalam perilaku sehari-hari. Ki Hajar Dewantara dalam hal ini menyatakan bahwa pendidikan adalah usaha yang dilakukan dengan penuh keinsyafan yang ditujukan untuk keselamatan dan kebahagiaan manusia. Pendidikan tidak hanya berfungsi sebagai pelaku pembangunan, tetapi sering merupakan perjuangan pula. Pendidikan berarti memelihara hidup tumbuh ke arah kemajuan, tidak boleh melanjutkan keadaan kemarin. Pendidikan adalah usaha kebudayaan, berasas peradaban, yakni memajukan hidup agar mempertinggi derajat kemanusiaan. ${ }^{29}$

Semangat progresif yang terkandung dalam pendidikan sebagaimana definisi di atas, tampak mengingatkan kita pada pesan Khalifah Umar yang mengatakan bahwa anak-anak muda masa sekarang adalah generasi di masa yang akan datang. ${ }^{30}$ Dunia dan kehidupan yang akan dihadapi berbeda dengan dunia yang sekarang, untuk itu apa yang akan diberikan pada anak didik harus memperlihatkan kemungkinan relevansi dan kegunaannya di masa datang.

\section{PEMBARUAN PENDIDIKAN ISLAM DALAM KONTEKS NASIONAL}

Pembaruan pendidikan ${ }^{31}$ menuntut adanya cara berpikir dan bertindak yang berbeda dari apa yang telah ada dengan mengadakan diagnosis secara menyeluruh atau perubahan paradigma dengan pendekatan yang sistemik. Paradigma yang sistemik mestilah bersifat menyeluruh serta memperhatikan sebuah asumsi mendasar bahwa perubahan mendasar pada salah satu aspek pendidikan akan mempengaruhi perubahan mendasar pada aspek-aspek lain. Perubahan itu dapat dibedakan pada empat lapis sistem yang saling berkaitan. Pada lapis pertama adalah perubahan pada pengalaman belajar, lapis kedua pada sistem pembelajaran yang menekankan terlaksananya pengalaman belajar yang diinginkan, seperti dalam sekolah. Lapis ketiga adalah perubahan pada pengalaman sistem pembelajaran, dan lapis keempat adalah perubahan pada sistem perundangan yang mengatur dan menjamin berlangsungnya keseluruhan sistem pendidikan secara nasional. ${ }^{32}$

Berdasarkan hakikat pembaruan sebagai pemberdayaan warga, sudah seharusnya perhatian utama diberikan pada perubahan lapis pertama, yaitu pengalaman belajar, dengan konsekuensi dan implikasi perubahan pada lapis kedua sampai keempat. Pendekatan mulai lapis pertama disebut pula sebagai pendekatan dari bawah ke atas (bottom-up approach). Selama 
ini apa yang terjadi adalah pendekatan dari atas ke bawah (top-down approach), di mana pemerintah pusat menentukan perundangan dan serangkaian peraturan pelaksanaan yang harus dipatuhi oleh jajaran di bawah sampai di ruang kelas atau lingkungan belajar tempat peserta didik atau warga belajar memperoleh dan mengembangkan pengalaman belajarnya. ${ }^{33}$

Dengan pendekatan dari bawah ke atas, perhatian utama diberikan kepada peserta didik agar mereka menguasai tugas belajar dan mampu mengatasi persoalan belajar. Semua satuan penyelenggara pendidikan, termasuk sekolah, pusat kegiatan belajar masyarakat, perguruan tinggi, dan sebagainya, wajib mengelola sumber daya yang diperlukan dan mengatur penggunaannya.

Perubahan paradigma mempengaruhi semua aspek pendidikan lain, bahkan memicu tumbuhnya serangkaian paradigma lain. Perubahan paradigma ini memunculkan konsep-konsep baru seperti belajar berbasis aneka sumber, pengelolaan berbasis sekolah dan pola pembelajaran atau pendekatan alternatif. ${ }^{34}$

Kesadaran untuk memajukan dunia pendidikan di Indonesia sesungguhnya telah tertanam kuat dalam jiwa para pendiri negara republik tercinta ini. Di antara isi pembukaan Undang-undang Dasar 1945 dengan tegas menyatakan bahwa salah satu tujuan pembentukan pemerintahan negara Indonesia ini adalah untuk mencerdaskan kehidupan bangsa. Citacita mencerdaskan kehidupan bangsa sebagaimana yang tertuang dalam pembukaan Undang-undang Dasar 1945 ini mengisyaratkan pentingnya memberikan pendidikan yang unggul dan merata bagi seluruh rakyat Indonesia sebagai modal untuk meraih kemajuan dalam berbagai bidang kehidupan lainnya. ${ }^{35}$

Kehidupan pada milenium ketiga benar-benar berada pada tingkat persaingan global yang sangat ketat. Artinya, siapa saja yang tidak memenuhi syarat kualitas global akan tersingkir secara alami dengan sendirinya. Untuk itu patut diperhatikan metafora John F. Kennedy, yaitu; "Change is a way of life. Those who look to the past or present will miss the future". Metafora ini pantas diterjemahkan ke dalam kepentingan reformasi pendidikan. Artinya, reformasi pendidikan harus tetap berpegang pada tantangan masa depan yang penuh dengan persaingan global. 36

Untuk merespons tantangan globalisasi dan modernisasi pendidikan Islam dalam konteks nasional dapat juga dilihat pada pandangan Malik Fadjar sebagai praktisi pendidikan yang mengatasi dualisme dan dikotomi menuju otonomi antara lain gagasannya adalah: 


\section{Pengembangan Fakultas Cabang Menjadi STAIN}

Dalam merespons perkembangan globalisasi, Malik Fadjar (ketika menjabat Dirjen Binbagais Departemen Agama) mengusulkan pembenahan dan rasionalisasi organisasi Perguruan Tinggi Agama Islam atau IAIN. ${ }^{37}$ Hasil dari rasionalisasi organisasi pada tahap praksisnya melahirkan Keputusan Presiden No. 11 Tahun 1997 yang menetapkan fakultas cabang di lingkungan IAIN berubah menjadi STAIN. ${ }^{38}$

Hal yang mendasari munculnya gagasan ini, sebagaimana yang diungkapkan oleh Malik Fadjar bahwa nama fakultas cabang itu sebetulnya bertentangan dengan undang-undang. Struktur Perguruan Tinggi yang benar adalah Universitas, Institut, Sekolah Tinggi, Akademi, dan Diploma, bukan fakultas cabang. Untuk kepentingan ini, Malik Fadjar melakukan komunikasi intensif dengan berbagai kalangan; dengan Depdiknas, Departemen Anggaran, Bappenas, Menpan, dan juga para anggota DPR. Terbitlah kemudian Keputusan Presiden No. 11 Tahun 1997 yang menyatakan 33 Fakultas Cabang IAIN menjadi STAIN. ${ }^{39}$

Gagasan memerdekakan fakultas cabang ini menjadi STAIN menurut Sofian Effendi muncul dari Malik Fadjar sendiri sesuai dengan pengalaman sebelumnya memimpin UMM. Perguruan Tinggi yang diinginkan oleh Malik Fadjar adalah Islamic Studies, yaitu pengembangan lembaga pendidikan dengan pendekatan modern yang didukung dengan berbagai aspek ilmu. Jadi, gaya dan semangat Malik Fadjar itu identik dengan Mukti Ali. ${ }^{40}$

Sementara itu Azyumardi Azra berpendapat bahwa tujuan Malik Fadjar dalam mengembangkan gagasan perubahan IAIN menjadi UIN kemudian pemisahan fakultas-fakultas cabang menjadi STAIN, supaya fakultas itu bisa mandiri dan dengan kemandiriannya bisa meningkatkan kualitas, tidak tergantung ke induknya yang selama ini dipandang kurang bisa memperhatikan, mengelola dan mengembangkannya dengan baik. ${ }^{41}$ Oleh karena itu, dapat dipahami bahwa gagasan sentral pemikiran Malik Fadjar ini adalah modernisasi dan pembaruan pendidikan Islam. ${ }^{42}$

Terkait dengan pengembangan jurusan menjadi STAIN ini menurut Husni Rahim bahwa gagasan Malik Fadjar ini sangat baik dan memberdayakan, tetapi daerah lebih mengedepankan kekuasaan dari pada kualitas dan fatalnya di daerah termasuk dosennya sangat kurang memperhatikan SDM. Hal ini seharusnya ada aturan yang menyikapi sehingga lebih mengedepankan kualitas daripada kekuasaan. Jadi, idenya bagus, tetapi ketika pelaksanaan di daerah tidak dijalankan secara komprehensif. 43 
Patut diapresiasi keberanian kebijakan yang diambil oleh A. Malik Fadjar, dengan terbentuknya 33 buah STAIN maka pengembangan IAIN mengalami babak baru. Dengan pendirian STAIN-STAIN ini, studi Islam di daerah-daerah diharapkan berkembang menjadi lebih mandiri. Dampaknya mulai terasa, sejumlah STAIN yang lebih kuat dapat berkembang lebih cepat, ${ }^{44}$ bahkan berubah menjadi UIN seperti halnya UIN Malang. Akan tetapi, STAIN yang lebih lemah akan semakin lemah, karena transfer dan subsidi tenaga dari manajemen dari bekas IAIN induknya menjadi sulit terjadi. Dampak lain dari pendirian STAIN ialah bahwa kurikulum IAIN sejak 1997 ternyata telah diatur dan diperlakukan seperti STAIN, khususnya dalam mengelompokkan MKDK dan MKK sehingga para dosen IAIN merasa seolah-olah kehilangan keberadaan fakultas mereka dan perbedaan kurikulum IAIN antar fakultas menjadi semakin tidak jelas. Sebabnya ialah bias dan dipakainya asumsi STAIN yang tentu saja tidak mempunyai fakultas-fakultas, bahkan nama-nama fakultas itu disebut sebagai nama jurusan pada STAIN.

\section{Pengembangan Jurusan di STAIN/IAIN}

Memahami dan merespons dinamika perkembangan pendidikan, Malik Fadjar (ketika Dirjen) secara praksis mengeluarkan Surat Keputusan Direktur Jenderal Pembinaan Kelembagaan Agama Islam Nomor E/107/ 1998 Tertanggal 13 Mei 1998 tentang Penyelenggaraan Jurusan Tarbiyah Program Studi Pendidikan Islam, Program Studi Tadris Matematika, Program Studi Tadris Ilmu Pengetahuan Alam, Program Diploma II (D-2) Pendidikan Agama Islam, Program Studi Kependidikan Islam; Jurusan Psikologi; Jurusan Adab/Bahasa Program Studi Bahasa Arab, Program Studi Bahasa Inggris; Jurusan Syariah Program Studi Ahwalus Syakhshiyah (Peradilan Agama) dan Program Studi Muamalah (Ekonomi Islam) pada STAIN Malang. 45

Di samping itu, Malik Fadjar (ketika Menag) mengeluarkan Surat Keputusan Direktorat Jenderal Pembinaan Kelembagaan Agama Islam Nomor E/138/1999, tentang Penyelenggaraan Jurusan Psikologi dan Jurusan Tarbiyah program studi Tadris IPS pada STAIN Malang. Pengembangan jurusan tersebut secara praksis merupakan respons positif dan konstruktif pada pengembangan lembaga pendidikan. ${ }^{46}$ Dengan begitu, lembaga tersebut diharapkan akan lebih mengalami kemajuan dan menguntungkan pada semua lini kehidupan.

Menurut Malik Fadjar, sesungguhnya gagasan tersebut dulu sudah ada di IAIN, seperti jurusan dan program studi; ada Jurusan Tadris MIPA, Bahasa Inggris, Tata Negara, Civic Ekonomi, Bahasa Indonesia, dan 
sebagainya. ${ }^{47}$ Akan tetapi, mengapa itu kemudian dihapuskan? Mengapa generasi berikutnya tidak mampu melanjutkan ide-ide besar yang dirintis pendahulunya?

Gagasan Malik Fadjar tentang pengembangan jurusan dalam kerangka pendidikan Islam tersebut di atas merupakan bibit dari konsep "wider mandate" (mandat yang di perluas), di mana peran Malik Fadjar waktu itu sebagai pembuka pintu wider mandate tersebut. ${ }^{48}$ Adapun tujuan dari wider mandate pada tahap praksisnya adalah untuk membuka jurusan umum dan mengembangkan lembaga pendidikan dalam merespons modernisasi dan globalisasi. Inilah target yang ingin dicapai oleh Malik Fadjar sebagaimana yang diungkapkan oleh Sofyan Effendi. ${ }^{49}$ Di samping itu menurut Tarmizi Taher adalah untuk mencapai pasar kerja yang kompetitif, baik pada masa itu maupun pada masa sekarang. ${ }^{50}$

Sementara itu menurut Azyumardi Azra bahwa dalam rangka mendukung perubahan IAIN menjadi UIN, maka perlu ada persiapan terlebih dahulu. Penyiapan itulah yang disebut dengan mandat yang lebih luas (wider mandate) yaitu dengan mengembangkan atau membentuk jurusanjurusan umum yang selama ini belum ada di IAIN. Sehingga IAIN tidak lagi terbatas pada ilmu-ilmu agama, melainkan juga mencakup ilmu-ilmu umum. 51

\section{Pengembangan STAIN/IAIN Menuju Universitas}

Gagasan perubahan STAIN/IAIN menjadi UIN yang diangankan Malik Fadjar bukan sekedar perubahan "papan nama", tetapi sebagai model "reintegrasi keilmuan" yang menunjuk kepada satu bentuk pengembangan, peningkatan dan pemantapan status akademik yang lebih proporsional dan profesional.52 Gagasan tersebut sejalan dengan semangat wider mandate (mandat diperluas) untuk memberikan wewenang kepada PTAI agar membuka jurusan sesuai kebutuhan pasar supaya bisa lebih modern dan mandiri.

Lembaga pendidikan tinggi agama sudah harus mendapatkan wider mandate, sebagai respons atas berbagai tantangan baru yang dihadapainya. Dengan mandat lebih luas ini, antara lain, IAIN secara praksis diharapkan mampu berpartisipasi dalam mengintegrasikan ilmu-ilmu normatif dengan ilmu-ilmu obyektif. 53 Tujuan dari perluasan mandat ini adalah reproduksi manusia akademis yang siap pakai dalam menghadapi tantangan zaman yang penuh dinamika di era global.

Malik Fadjar menyatakan bahwa UIN ke depan dapat menjadi model sistem pendidikan Islam yang memiliki "kualitas tinggi" dibandingkan dengan PTN/PTS yang lain yang memiliki status, peran dan fungsi yang 
sama, di samping memiliki otonomi lebih luas baik dalam pengembangan akademik, manajemen maupun admistrasinya. ${ }^{54}$ Dengan penataan elemenelemen lembaga pendidikan secara menyeluruh yang didesain dengan teknologi yang maju, maka lembaga pendidikan Islam akan mampu memenuhi logika persaingan pasar ke depan.

Dengan berubahnya IAIN Jakarta menjadi UIN, misalnya, dapat diasumsikan sebagai langkah dinamis untuk "membangun sistem pendidikan yang integralistik dan komprehensif dalam berbagai disiplin ilmu dalam rangka memenuhi tuntutan dan kebutuhan masyarakat terhadap lembaga pendidikan tinggi yang mampu menghasilkan intelektual yang profesional dan bermoral". 55

Dari berbagai latar belakang dan tujuan tersebut, terlihat bahwa ide perubahan lembaga PTAI bersumber dari perenungan internal dan eksternal tentang posisi dan fungsi yang selama ini dijalani oleh IAIN serta respons terhadap realitas yang berkembang dalam masyarakat. 56 Perenungan internal telah merevisi cara pandang IAIN dan Departemen Agama tentang konstruksi keilmuan yang "sesungguhnya" yang bersifat non-dikotomis. Sedangkan perenungan eksternal telah "membuka mata" mereka tentang kebutuhan-kebutuhan yang berkembang di masyarakat sehingga perlu disikapi secara konkret. Perenungan seperti ini telah membawa perubahan mental akademik yang sejajar dengan lembaga-lembaga pendidikan lain dan menyatukan ilmu yang dikotomi menuju otonomi sehingga akan melahirkan wawasan keilmuan yang lebih luas dan lues.

UIN yang dicita-citakan sebagai center of exellence bagi pengembangan keilmuan pada umumnya dan keilmuan Islam pada khususnya, sehingga terbentuk komunitas ilmiah-religius (religious-scientific community) yang bersendikan ajaran agama, bukan sekadar pengawal, penjaga, dan pelestari tradisi yang ada. UIN diharapkan tidak saja piawai sebagai pencetak 'guru agama' dan kiai tradisional, melainkan bagaimana bisa melahirkan kiai-kiai profesional di dalam mengurus pesantren perikanan, pesantren peternakan, pesantren perkebunan, pesantren pertambangan, pesantren perindustrian, dan sebagainya. Tentu dengan pengejawantahan secara profesional di setiap bidang akademik yang dibuka. ${ }^{57}$

Apa yang digagas oleh Malik Fadjar dapat memberi pemahaman bahwa pengembangan STAIN/IAIN menuju UIN kiranya merupakan langkah strategis dan futuristik. Melalui pengembangan STAIN/IAIN menuju UIN ini, Malik Fadjar meyakini bahwa umat Islam bisa memainkan peran yang sesungguhnya di dalam pergaulan global. Memaknai ini, Malik Fadjar mengemukakan: bahwa masa depan harus dijemput dengan menggunakan sarana pendidikan. Oleh karena itu, pendidikan harus dipacu ke 
arah masa depan manusia. Di sinilah sesungguhnya makna pentingnya secara terus-menerus memperbarui sistem pendidikan Islam. Ungkapan long life education, sejatinya sudah disuguhkan oleh Nabi saw. ketika menyuruh para sahabat belajar ilmu ke Cina (uthlub al-'ilm wa law bi alshin) yang artinya carilah ilmu walau sampai ke negeri Cina (hadis) dan mencari ilmu sejak lahir sampai mati (uthlub al-ilm min al-mahdi ila al-lahd) yang artinya carilah ilmu sejak dari buaian sampai engkau meninggal dunia (hadis). Untuk itu, manusia harus senantiasa belajar dan belajar (learn how to learn). Belajar itu merupakan rekreasi ke arah masa depan. 58

Gagasan pembaruan tersebut di atas tidak dapat dibayangkan seandainya tidak ada Malik Fadjar (Mendiknas) dan Azyumardi Azra (Rektor UIN Jakarta) waktu itu yang gigih mengubah pola pikir masyarakat dari dikotomi menuju otonomi pendidikan. Integrasi pendidikan tersebut diikuti oleh lembaga-lembaga lain dalam rangka merespons tantangan globalisasi dan otonomisasi.

Pembaruan pendidikan pada dasarnya memiliki tujuan agar pendidikan dapat berjalan lebih efektif dan efisien mencapai tujuan pendidikan nasional. ${ }^{59}$ Untuk itu dalam pembaruan terdapat dua hal yang perlu dilakukan: a) mengidentifikasi berbagai problem yang menghambat terlaksananya pendidikan; dan b) merumuskan reformasi yang bersifat strategis dan praktis sehingga dapat diimplementasikan di lapangan.

Oleh karena itu, kondisi yang diperlukan dan program aksi yang harus diciptakan merupakan titik sentral yang harus diperhatikan dalam setiap reformasi pendidikan. Dengan kata lain, reformasi pendidikan harus mendasarkan pada realitas sekolah yang ada bukan mendasarkan pada etalase atau jargon-jargon pendidikan semata. Reformasi hendaknya didasarkan fakta dan hasil penelitian yang memadai dan valid, sehingga dapat dikembangkan program reformasi yang utuh, jelas, dan realistis. ${ }^{60}$

Untuk menciptakan keunggulan kompetitif, bangsa Indonesia memerlukan inovasi yang pesat dalam dunia pendidikan. Menjadi bangsa yang berharkat memerlukan keunggulan yang kompetitif dalam berbagai bidang. Bukan zamannya lagi mengandalkan murahnya tenaga kerja untuk mendukung dan membenarkan konsep keunggulan komparatif dan kompetitif. ${ }^{61}$ Dalam konteks untuk menciptakan keunggulan yang kompetitif sebagai outcome suatu pendidikan patut kiranya dikaji pendapat Michael Porter yang mengungkapkan bahwa: the ability to sustain an advantage from cheap labor or even from economies of scale-these are the old paradigms. These paradigms are being supertseded. Today, the only way to have an advantage is through innovation an upgrading. ${ }^{62}$

Dari pendapat Porter di atas, jika bangsa Indonesia ingin menghasilkan berbagai keunggulan kompetitif dari outcome pendidikan, inovasi 
harus menjadi prioritas penting dalam pengembangan sistem pendidikan. Tanpa ada inovasi yang signifikan, pendidikan nasional hanya akan menghasilkan lulusan yang tidak mandiri, selalu bergantung pada pihak lain. Dalam perspektif global, hasil pendidikan yang demikian itu justru akan menjadi beban bagi bangsa dan negara, sekaligus bagi masyarakat. 63

Menurut Azyumardi Azra, perumusan konsep tentang reformasi pendidikan, arah baru pendidikan nasional, yang bisa disebut sebagai salah satu fungsi pokok dan tujuan akhir pendidikan, adalah mempersiapkan individu anak didik dan warga masyarakat yang memiliki kemampuan untuk mengaktualisasikan, melembagakan, dan mengembangkan masyarakat madani Indonesia, yang akan dibahas lebih rinci di bawah.

Untuk mencapai tujuan tersebut, kebijaksanaan pendidikan nasional jangka panjang seharusnya bertumpu pada usaha-usaha: pertama, menjamin kesempatan (equity) bagi setiap anak bangsa untuk memperoleh pendidikan yang selaras dengan kebutuhan masyarakat lingkungan masing-masing, dan pada saat yang sama juga memberikan peluang yang luas bagi peningkatan kemampuan pendidikan masyarakat dengan memberikan kesempatan bagi diversifikasi program pendidikan. Kedua, menyelenggarakan pendidikan yang relevan dan bermutu sesuai dengan kebutuhan masyarakat madani Indonesia dalam menghadapi tantangan global, dan pada saat yang sama meningkatkan efisiensi internal dan eksternal pada semua jalur, jenjang, dan jenis pendidikan. Ketiga, menyelenggarakan sistem pendidikan yang demokratis dan profesional yang dapat dipertanggungjawabkan (accountable) bagi masyarakat dan seluruh stakeholders lainnya. Keempat, mengurangi peranan pemerintah, sehingga lebih merupakan fasilitator dalam implementasi sistem pendidikan, dan pada saat yang sama merampingkan birokrasi pendidikan agar lebih fleksibel dalam merespons perubahan dan dinamika perkembangan masyarakat baik di tingkat nasional maupun global.

Berdasarkan kerangka arah dan kebijakan pendidikan nasional jangka panjang itu, selanjutnya dapat dirumuskan arah, kebijakan dan strategi pendidikan nasional, baik untuk jangka menengah dan jangka pendek. Rincian-rincian dari semua arah, kebijakan, dan strategi pendidikan tersebut agaknya tidak perlu dikemukakan di sini. Yang penting ditekankan adalah bahwa sistem dan proses pendidikan nasional, sekali lagi, mestilah memberikan penekanan sangat kuat bagi penyiapan anak bangsa agar memiliki kemampuan, kecakapan, dan motivasi dalam aktualisasi dan institusionalisasi masyarakat madani Indonesia. Di sini juga jelas, bahwa "nation and character building" harus menjadi inti dan salah satu tujuan pokok pendidikan nasional. ${ }^{64}$ 
Upaya pembaruan diarahkan kepada sistem pendidikan, termasuk pembaruan kurikulum, pemberdayaan sekolah sebagai pusat pembudayaan nilai, sikap dan kemampuan, serta pembaruan dan pemantapan sistem pendidikan nasional berdasarkan prinsip desentralisasi, otonomi keilmuan, dan manajemen. Pembaruan dimaksud didukung dengan kebijakan politik yang diarahkan untuk meningkatkan peran DPR/MPR dan lembaga tinggi negara lainnya dengan menegakkan fungsi dan tanggung jawab yang mengacu pada prinsip pembagian kekuasaan dan tata hubungan yang jelas antara lembaga eksekutif, legeslatif, dan yudikatif. Untuk lebih jelasnya dapat dilihat pada bagan berikut ini:

Hubungan Pendidikan Agama dengan Sistem Pendidikan Nasional

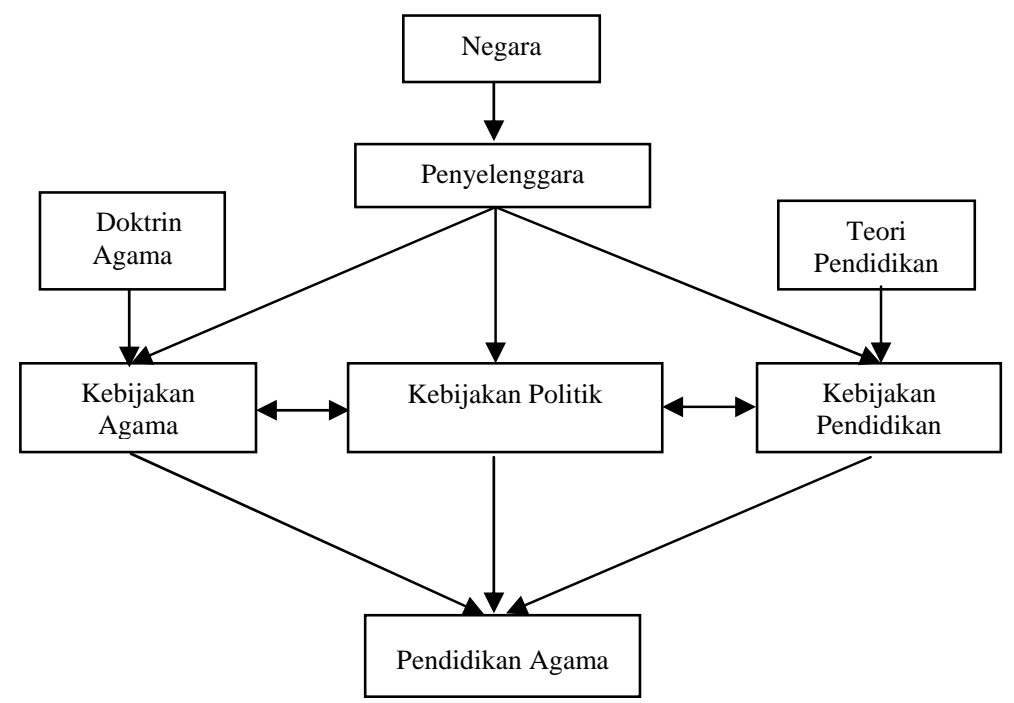

Bertolak dari hal di atas dapat dipahami bahwa kebijakan agama diperlukan oleh pendidikan agama sebagai penegak eksistensi dogmatik. Kebijakan pendidikan dibutuhkan sebagai penegak eksistensi struktural. Adapun kebijakan politik diperlukan sebagai peletak dan penegak dasar yuridis. ${ }^{65}$

Oleh karena itu, pendidikan harus berperan sebagai sarana pemberdayaan (empowerment) yang secara sadar menyiapkan peserta didik dalam kehidupan masyarakat baik sebagai individu maupun sebagai anggota masyarakat. Dengan kata lain, pendidikan berfungsi sebagai sarana pemberdayaan individu dan masyarakat guna menghadapi masa depan. Pemberdayaan hanya mempunyai makna jika proses pemberdayaan menjadi bagian dan fungsi dari kebudayaan. Pendidikan Islam yang berdaya dan memberdayakan akan mewujud apabila:

a. Memiliki visi, misi, dan orientasi strategis ke depan yang jelas;

b. Memiliki legitimasi sosial, intelektual, dan moral yang kuat; 
c. Berbasis pada masyarakat dan merespons tuntutan zaman;

d. Dikelola dengan manajemen modern yang profesional, rasional; terbuka, akuntabel, humanis, memiliki akses, kerja sama, dan kemitraan global.

\section{PENUTUP}

Pembaruan pendidikan pada dasarnya memiliki tujuan agar pendidikan dapat berjalan lebih efektif dan efisien dalam mencapai tujuan pendidikan nasional. Hal tersebut dapat dilihat antara lain berubahnya fakultas cabang di lingkungan IAIN menjadi STAIN. Jurusan dapat dikembangkan sesuai kebutuhan pasar. Di antaranya: Jurusan Tarbiyah program studi pendidikan Islam, program studi tadris metematika, program studi tadris ilmu pengetahuan alam, program diploma II (D-2) pendidikan agama Islam, program studi kependidikan Islam. Jurusan Psikologi, Jurusan Adab/Bahasa program studi bahasa Arab, program studi bahasa Inggris, Jurusan Syariah program studi ahwalus syakhsyiyah (peradilan agama) dan program studi muamalah (ekonomi Islam) pada STAIN Malang. IAIN/STAIN menuju UIN. Hal tersebut merupakan respons positif dan konstruktif terhadap tantangan dunia pendidikan yang menglobal. Dengan demikian dapat memproduk alumni-alumni yang memiliki competitive adventage, daya saing yang handal dan tangguh dalam menghadapi tantangan zaman. Perubahan IAIN menjadi UIN, dapat dilihat antara lain diresmikannya UIN Jakarta, UIN Sunan Kalijaga Yokyakarta dan UIN Malang. Menyusul kemudian UIN Pekan Baru Riau, UIN Makassar dan UIN Bandung.

Gagasan pembaruan tersebut merupakan respons positif dan konstruktif dari tantangan globalisasi, otonomisasi, dan modernisasi dalam upaya memajukan dunia pendidikan secara rasional dan nasional. Upaya tersebut sebagai salah satu fungsi terlaksananya sistem dan kebijakan pemerintah secara nasional. Tujuannya agar pendidikan agama lebih terpadu dan integral dengan sistem pendidikan nasional.

\section{CATATAN AKHIR:}

1. Lihat Suyanto, Dinamika Pendidikan Nasional (Dalam Percaturan Dunia Global), Jakarta: PSAP Muhammadiyah, 2006, h. ix

2. Suwito, "Pendidikan yang Memberdayakan", Pidato Pengukuhan Guru Besar, IAIN Syarif Hidayatullah Jakarta Tanggal 3 Januari 2002, h. 1.

3. Azyumardi Azra, Pendidikan Islam: Tradisi dan Modernisasi Menuju Milenium Baru, Jakarta: Logos Wacana Ilmu, 1999, h. 17.

4. Azyumardi Azra, Pendidikan Islam: Tradisi dan Modernisasi Menuju Milenium Baru, h. 17. 
5. Zamrozi, Paradigma Pendidikan di Masa Depan, Yogyakarta: Bayu Indra Grafika, 2000, h. 158.

6. Indra Djati Sidi, Menuju Masyarakat Belajar: Menggagas Paradigma Baru Pendidikan, Jakarta: Paramadina, 2001, h. 14.

7. Malik Fadjar, Visi Pembaruan Pendidikan Islam, Jakarta: Lembaga Pengembangan Pendidikan dan Penyusunan Naskah Indonesia, 1998, h.3. Lihat juga Malik Fadjar, "Pengembangan Pendidikan Islam yang Menjanjikan Masa Depan" dalam Jurnal Edukasi Volume 2, Nomor 1, Januari-Maret 2004.

8. Pada pasal 30 bagian kesembilan ayat 4 dijelaskan bahwa pendidikan keagamaan berbentuk pendidikan diniyah, pesantren, pasraman, pabhaja samanera, dan bentuk lain yang sejenis. Lihat Undang-undang Nomor 20 Tahun 2003 tentang Sistem Pendidikan Nasional, h. 14.

9. Malik Fadjar, "Pengembangan Pendidikan Islam yang Menjanjikan Masa Depan", dalam Muhammad In'am Esha dan Helmi Syaifuddin (ed.) Kumpulan Orasi Ilmiah Pengukuhan Guru Besar UIN Malang Periode 1989-2006, Malang: UIN Malang Press, 2006, h. 144-145.

10. Malik Fadjar, Reorientasi Pendidikan Islam, h. 31.

11. Malik Fadjar, Visi Pembaruan Pendidikan Islam, h. 4.

12. Malik Fadjar, Visi Pembaruan Pendidikan Islam, h. 4.

13. Azyumardi Azra, Islam Subtantif: Agar Umat Tidak Jadi Buih, Bandung: Mizan, 2000, h. 132.

14. Malik Fadjar, "Mencari Dasar Filosofi Pendidikan Islam; Sebuah Tinjauan Terhadap Pendidikan Kemuhammadiyahan dan Al-Islam, dalam Imron Nasri dan A. Hasan Kunio, (ed), Di Seputar Percakapan Pendidikan dalam Muhammadiyah, Yogyakarta: Pustaka SM, 1994, h. 21-22.

15. Hamka, Lembaga Hidup, Jakarta: Djajamurni, 1962, h. 204.

16. Muhammad Abduh, "Al-Madāris al-Tajhizāt wa al-Madāris al-Aliyāt" dalam Imarah, al-A'māl al-Kämil Li al-Imām Muhammad Abduh, Bairut: al-Muassasah alArabiyah li al-Dirasah wa al-Nashr, 1972, Juz III, h. 117.

17. Muhammad Athiyah al-Abrasyi, al-Tarbiyah al-Islämiyyah wa Falsafatuhā, Kairo: Isa al-Babi al-Halabi, 1969, h. 37.

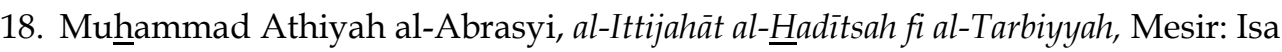
al-Babi al-Halabi, t.th., h. 263.

19. Ahmad Tafsir, Ilmu Pendidikan dalam Perspektif Islam, Bandung: PT Remaja Rosda Karya, 1994, h. 46.

20. Hasan Syahāātah, Ta'lìm al-Dìn al-Islāmì baina al-Nazhariyah wa al-Tathbìq, Kairo: Maktabah al-Dar al-'Arabiyah lilkitab, 1994, h. 21. Lihat juga Muhammad Abd al-Qādir Ahmad, Thuruq Ta'līm al-Tarbiyyah al-Islāmiyyah, Kairo: Maktabah Nahdhah al-Mishrah, 1981, h. 19.

21. Majîd Irsān al-Kailāni, Falsafāt al-Tarbiyyah al-Islāmiyyah, Makah: Maktabah Hadi, 1988, h. 83

22. Abdurraḩman al-Nahlawi, Ushūl al-Tarbiyyah al-Islāmiyyah fi al-Bait wa alMadrasah wa al-Mujtama', Damaskus: Dar al-Fikr, 1996, h. 20.

23. Ahmad Fu'ad al-Ahwani, Al-Tarbiyyah fi al-Isläm, Kairo: Dar al-Ma'arif, t.th., h. 97.

24. Muhammad Rasyid Ridha, Tārikh al-Ustādz al-Imām al-Syaikh Muhammad Abduh, Mesir: al-Manar, 1931, Jilid II, h. 17. 
25. Jum C. Nunnalli, Educational Mesurement and Evaluation, New York: Hill Book Company, t.th., h. 16.

26. Fuad Hassan, "Pendidikan adalah Pembudayaan", dalam Tonny D. Widiastono (ed.), Pendidikan Manusia Indonesia, h. 64.

27. Fuad Hassan, "Pendidikan adalah Pembudayaan", dalam Tonny D. Widiastono. ed, Pendidikan Manusia Indonesia, h. 64.

28. Azyumardi Azra, Pendidikan Islam Tradisi dan Modernisasi Menuju Milenium Baru, Jakarta: PT. Logos Wacana Ilmu, 1999, h. 10.

29. Ki Hajar Dewantara, Bagian Pertama Pendidikan, Yogyakarta: Majlis Luhur Persatuan Taman Siswa, 1962, h. 19.

30. Abudin Nata, Filsafat Pendidikan Islam, Jakarta: Logos Wacana Ilmu, 2001, h. 910.

31. Lihat Zamrozi, Paradigma Pendidikan di Masa Depan, h. 159

32. Yusufhadi Miarso, "Perubahan Paradigma Pendidikan Peran Tekhnologi Pendidikan dalam Penyampaian Misi dan Informasi Pendidikan" dalam Menyemai Benih Tekhnologi Pendidikan, Jakarta: Kencana, 2005, h. 694.

33. Lihat Yusufhadi Miarso, Menyemai Benih Tekhnologi Pendidikan, h. 694.

34. Lihat Yusufhadi Miarso, "Perubahan Paradigma Pendidikan Peran Tekhnologi Pendidikan Dalam Penyampaian Misi dan Informasi Pendidikan" dalam Menyemai Benih Tekhnologi Pendidikan, h. 696-698.

35. Abuddin Nata, Modernisasi Pendidikan Islam di Indonesia, Jakarta: UIN Jakarta Press, 2002, h. 5.

36. Suyanto dan Jihad Hisyam, Refleksi dan Reformasi Pendidikan di Indonesia Memasuki Millenium III, Yogyakarta: Adi Cita Karya Nusa, 2000, h. 2.

37. Terdapat 14 IAIN yang tercatat di Depag sampai tahun 2001. Lihat Suwito, Pendidikan yang Memberdayakan, pidato pengukuhan Guru Besar, 3 Januari 2001.

38. Malik Fadjar, Holistika Pemikiran Pendidikan, h. 35.

39. Tercatat 33 STAIN di seluruh Indonesia sampai saat ini. Lihat Direktori Perguruan Tinggi Agama Islam Negeri 2000-2001.

40. Muhammad Idris, Disertasi Sekolah Pascasarjana UIN Jakarta 2008.

41. Muhammad Idris, Disertasi Sekolah Pascasarjana UIN Jakarta 2008.

42. Muhammad Idris, Disertasi Sekolah Pascasarjana UIN Jakarta 2008.

43. Muhammad Idris, Disertasi Sekolah Pasca sarjana UIN Jakarta 2008.

44. http://www.ditpertais.net/artikel/atho01.htm. Tanggal 19 Desember 2007. Kedudukan IAIN Sebagai Perguruan Tinggi.

45. Malik Fadjar Fadjar, Holistika Pemikiran Pendidikan, h. 36-37.

46. Himpunan Peraturan Perundang-undangan produk Departemen Agama tahun 1999 yang dibuat oleh Biro Hukum dan Humas Depag RI.

47. Malik Fadjar, Holistika Pemikiran Pendidikan, h. 36.

48. Muh. Idris, Disertasi Sekolah Pasca sarjana UIN Jakarta 2008.

49. Muh. Idris, Disertasi Sekolah Pasca sarjana UIN Jakarta 2008.

50. Muh. Idris, Disertasi Sekolah Pasca sarjana UIN Jakarta 2008.

51. Muh. Idris, Disertasi Sekolah Pasca sarjana UIN Jakarta 2008.

52. Malik Fadjar, Holistika Pemikiran Pendidikan, h.37. 
53. Fachry Ali, Kontinuitas dan Perubahan: Catatan Sejarah Sosial Budaya Alumni IAIN dalam Problem dan Prospek IAIN, Jakarta: Ditbinperta, 2000, h. 371.

54. Malik Fadjar, Holistika Pemikiran Pendidikan, h. 37.

55. IAIN Syarif Hidayatullah, Proposal Konversi IAIN Menjadi Universitas Islam Negeri (UIN) Syarif Hidayatullah Jakarta, Jakarta, 2000. h. 5.

56. Suwito dan Suparto, "IAIN Menjadi Universitas", dalam Mimbar Agama dan Budaya, Vol. XVIII,No. 2, 2000, h. 155.

57. Imam Tholkhah dan Ahmad Barizi, Membuka Jendela Pendidikan: Mengurai Akar Tradisi dan Integrasi Keilmuan Pendidikan Islam, h. 108.

58. Malik Fadjar, Holistika Pemikiran Pendidikan, h.38.

59. Terdapat 14 IAIN yang tercatat di Depag sampai tahun 2001.

60. Zamrozi, Paradigma Pendidikan di Masa Depan, h. 160.

61. Suyanto, Dinamika Pendidikan Nasional (Dalam Percaturan Dunia Global), h. 7.

62. Michael Porter, "Creating Tomorrow's Advantages" in Rowan Gibson (ed), Rethinking the Future, London: Nicholas Brealey Publishing Limited, 1997, h. 54.

63. Suyanto, Dinamika Pendidikan Nasional (Dalam Percaturan Dunia Global), h. 7. Lihat R. C. Wallace Jr, The Learning School: A Guide to Vision-Based Leadership, California: Corwin Press, 1997, h. 4.

64. Azyumardi Azrah, Paradigma Baru Pendidikan Nasional: Rekonstruksi dan Demokratisasi, Jakarta, Penerbit Buku Kompas, 2002.

65. M. Saerozi, "Bila Negara Mengatur Agama: Konfesionalitas Kebijakan Pendidikan Nasional" dalam Ulumuna, vol. VII, edisi 12 No. 2 Juli-Desember 2003, h. 267-268.

\section{DAFTAR PUSTAKA}

Abduh, Muhammad, "Al-Madāris al-Tajhizāt wa al-Madāris al-Aliyāt" dalam Imarah, al-A'māl al-Kāmil Li al-Imām Muhammad Abduh, juz III, Bairut: alMuassasah al-Arabiyah li al-Dirasah wa al-Nashr, 1972, Juz III.

Al-Abrasyi, M. Athiyah, al-Tarbiyyah al-Islāmiyyah wa Falsafatuhā, Mesir: Isa al-Babi al-Halabi, 1975.

Al-Ainain, Abu Khalil Abu, Falsafah al-Tarbiyyah al-Islāmiyyah fì al-Qur'ān al-Karìm, t.t: Dar al-Fikr al-Arabi, 1980.

Al-Ahwwani, Ahmad Fu'ad, Al-Tarbiyyah fi al-Islām, Kairo: Dar al-Ma'arif, t.th.

Ali, M. Natsir, Dasar-dasar Ilmu Mendidik, Jakarta: Mutiara, 1997.

Ali, Fachry, Kontinuitas dan Perubahan: Catatan Sejarah Sosial Budaya Alumni IAIN dalam Problem dan Prospek IAIN, Jakarta: Ditbinperta, 2000.

Arief, Armai, Reformulasi Pendidikan Islam, Jakarta: CRSD Press, 2005.

Arifin, Muzayyin, Filsafat Pendidikan Islam, Jakarta: PT Bina Aksara, 1987.

Al-Attas, Syed Muhammad Naquib, Konsep Pendidikan dalam Islam, Bandung: Mizan, 1984.

Ashraf, New Horizon in Muslim Education, London: The Islamic Academy, Cambridge University, 1985.

Azra, Azyumardi, Paradigma Baru Pendidikan Nasional: Rekonstruksi dan Demokratisasi, Jakarta, Penerbit Buku Kompas, 2002.

,"Praktek Pendidikan Islam: Akselerasi Perkembangan dan Tantangan 
Perubahan", dalam Kusmana dan JM Muslimin (Ed.), Paradigma Baru Pendidikan: Restropeksi dan Proyeksi Modernisasi Pendidikan Islam di Indonesia, Jakarta: IAIN Indonesia Social Equity Project (IISEP) bekerjasama Direktorat Pendidikan Tinggi Islam, Direktorat Jenderal Pendidikan Islam, Departemen Agama RI, 2008.

Beane, J.A, Toepfer, C.F. Allesi, S.J. Curriculum Planing and Development, Boston: Allyn and Bacon, Inc, 1986.

Bocock, Jean dan David Watson (ed), Managing University Curriculum Making Common Cause, Buckingham: SRHE and Open University Press, 1994.

Bruner, Jerome S, The Relevance of Education, (New York: W.W. Norton \& Company. Inc, 1973.

Daud, Wan Mohd Nor Wan, The Concept of Knowledge in Islam and its Implications for Education in a Developing Country, New York: Mansell, 2002.

Dewantara, Ki Hajar, Bagian Pertama Pendidikan, Yogyakarta: Majlis Luhur Persatuan Taman Siswa, 1962.

Undang-undang Republik Indonesia Nomor 20 Tahun 2003 tentang Sistem Pendidikan Nasional.

Fadjar, A. Malik, Reorientasi Pendidikan Islam, Jakarta: Fajar Dunia: 1999.

Hamka, Lembaga Hidup, Jakarta: Djajamurni, 1962.

Hidayat, Komaruddin, "Memetakan Kembali Struktur Keilmuan Islam", dalam Fuaduddin dan Cik Hasan Bisri, Dinamika Pemikiran Islam di Perguruan Tinggi: Wacana Tentang Pendidikan Agama Islam, Jakarta: Logos, 2002.

Himpunan Peraturan Perundang-undangan Produk Departemen Agama tahun 1999 yang dibuat oleh Biro Hukum dan Humas Depag RI.

http://www.ditpertais.net/artikel/atho01.htm. Tanggal 19 Desember 2007.

IAIN Syarif Hidayatullah, Proposal Konversi IAIN Menjadi Universitas Islam Negeri (UIN) Syarif Hidayatullah Jakarta, Jakarta, 2000.

Idris, Muhammad, Disertasi Sekolah Pasca sarjana UIN Jakarta 2008.

Imam Tholkhah dan Ahmad Barizi, Membuka Jendela Pendidikan: Mengurai Akar Tradisi dan Integrasi Keilmuan Pendidikan Islam.

Iqbal, Muhammad, The Reconstruction of Religions Thought in Islam, New Delhi: Kitab Bhavan, 1981.

Al-Kailani, Majid 'Arsan, Al-Fikr al-Tarbawi 'inda Ibn Taimiyah, Madinah alMunawwarah, Maktabah Dar al-Turas, t.th.

Kerr, Clark, The Uses of The University, New York: Harper \& Row, 1966.

Perubahan UUD 1945 dan Ketetapan-ketetapan SU-MPR Tahun 1999, Jakarta: Rineka Cipta, 1999.

M. Saerozi, “Bila Negara Mengatur Agama: Konfesionalitas Kebijakan Pendidikan Nasional" dalam Ulumuna Vol. VII Edisi 12 No. 2 Juli-Desember 2003.

Mahfuz, Syekh Ali, Hidayat al-Mursyidin; Kairo: al-Matba'at al-Usmaniyyah alMisiyyah, 1958.

Marimba, Ahmad D. Marimba, Pengantar Filsafat Pendidikan Islam, Bandung: PT. alMa'arif, 1981.

Miarso, Yusufhadi, "Perubahan Paradigma Pendidikan Peran Teknologi Pendidikan dalam Penyampaian Misi dan Informasi Pendidikan" dalam Menyemai Benih Tekhnologi Pendidikan, Jakarta: Kencana, 2005.

Muhaimin, Nuansa Baru Pendidikan Islam Mengurai Benang Kusut Dunia Pendidikan, Jakarta: PT RajaGrafindo Persada, 2006. 
McNeil, John, Curriculum A Comprehensive Introduction, Boston: Little, Brown and Company (Inc), 1977.

Nabi, Malik bin, Membangun Dunia Baru Islam, Penerjemah Afif Muhammad dan Abdul Adhiem, Bandung: Mizan, 1995.

Nata, Abuddin, Filsafat Pendidikan Islam, Jakarta: Logos Wacana Ilmu, 2001.

------, Modernisasi Pendidikan Islam di Indonesia, Jakarta:UIN Jakarta Press, 2002.

Nuh, Sayyid Muhammad, Manhaj ahl al-Sunnah wa al-Jamā'ah fi Qadiyyat alTaqayyur bi Janibaih al-Tarbawi wa al-Da'awiy, t.tp.: Dar al-Wafa al-Tiba'ah wa al-Nasyr, 1991.

Porter, Michael "Creating Tomorrow's Advantages" in Rowan Gibson (ed), Rethinking the Future, London: Nicholas Brealey Publishing Limited, 1997.

Rahim, Husni, “Madrasah Menggugat, Madrasah Digugat, dalam Jamaluddin (ed), Mendiskusikan Kembali Eksistensi Madrasah, Jakarta: Logos, 2003.

Rahman, Fazlur, Islam and Modernitas, Transformation of an Intelectual Tradition, Chicago: The University of Chicago Press, 1982.

Ridha, Muhammad Rasyid, Tārikh al-Ustāz al-Imām al-Syaikh Muhammad Abduh, Mesir: al-Manar, 1931.

Sidi, Indra Djati, Menuju Masyarakat Belajar: Menggagas Paradigma Baru Pendidikan, Jakarta: Paramadina, 2001.

Suwito dan Suparto, "IAIN Menjadi Universitas", dalam Mimbar Agama dan Budaya, Vol. XVIII, No.2, 2000, h. 155.

-------, Pendidikan yang Memberdayakan, Pidato Pengukuhan Guru Besar Sejarah dan Pemikiran Pendidikan Islam IAIN Syahid Jakarta Tgl 3 Januari 2002.

Suyanto, Dinamika Pendidikan Nasional (Dalam Percaturan Dunia Global), Jakarta: PSAP Muhammadiyah, 2006.

-------, Refleksi dan Reformasi Pendidikan di Indonesia Memasuki Millenium III, Yogyakarta: Adi Cita Karya Nusa, 2000.

Tafsir, Ahmad, Ilmu Pendidikan dalam Perspektif Islam, Bandung: PT Remaja Rosda Karya, 1994.

Tibi, Bassam, Islam and The Cultural Accomodation of Social Change, Penerjemah Clare Krojzl, Oxford: Westview Press, 1990.

Wahid, Syed Abdul, Thought and Reflektions of Iqbal, Lahore: Muh. Ashraf. 1964.

Wallace Jr, R.C., The Learning School: A Guide to Vision-Based Leadership, California: Corwin Press, 1997.

Zamrozi, Paradigma Pendidikan di Masa Depan, Yogya: Bayu Indra Grafika, 2000. 